\title{
Joe C. B. Leung and Yuebin Xu, China's Social Welfare,
} Cambridge, UK, Malden, MA, Polity Press, 2015, 224 pp.

\section{Carine Milcent}

Translator. David Buchanan

\section{OpenEdition}

\section{Journals}

\section{Electronic version}

URL: http://journals.openedition.org/chinaperspectives/7000

DOI: 10.4000/chinaperspectives.7000

ISSN: 1996-4617

\section{Publisher}

Centre d'étude français sur la Chine contemporaine

\section{Printed version}

Date of publication: 1 June 2016

Number of pages: $73-75$

ISSN: 2070-3449

\section{Electronic reference}

Carine Milcent, « Joe C. B. Leung and Yuebin Xu, China's Social Welfare, », China Perspectives [Online], 2016/2 | 2016, Online since 01 June 2016, connection on 24 September 2020. URL : http:// journals.openedition.org/chinaperspectives/7000 ; DOI : https://doi.org/10.4000/chinaperspectives. 7000

(c) All rights reserved 
solidified between local state power and transnational economic forces, helping generate considerable surplus value to the detriment of workers' security and health and in some cases even their lives.

Third, the voices and personalities of migrant workers are on the whole less present than in Made in China. The book pays greater attention to the structures of domination and to the political economy of the sectors studied. Perhaps this evolution in the author's work reflects a more pronounced mobilisation of Marxist-inspired analytical tools. It appears that the lesser attention to ethnographic details in Migrant Labor in China nevertheless permits a more profound description of politico-institutional, legal, and economic configurations behind the functioning of contemporary industrial capitalism and its complex modalities of reinvention and redeployment. Of course this stress on domination was already present in the author's previous work. In particular, her first article in 1999 (2) minutely described the spatio-temporal control over female workers in the production regime of a Shenzhen factory, combining Foucauldian and Marxist approaches; or again her description of the triple constraints - patriarchy, Party-state, and global capitalism - fashioning the subjectivity of rural women when it comes to their decision to leave their villages. But in Migrant Labor in China, Pun goes beyond descriptions of a specific production regime or political economy of labour in Shenzhen in particular, in order to expose politico-institutional processes in the countryside and in urban zones that have led to the development of a labour market largely benefiting capital accumulation, engendering what the author terms an "unfinished process of proletarianization" enabling "a production regime within which a separation exists between the production sphere in industrial regions and social reproduction in rural areas" (pp. 33-34). Migrant Labor in China also sheds light on the transformations in contemporary industrial capitalism through the study of the Foxconn group, which represents, according to the author, an example of concentration and centralisation of capital on "an unimaginable scale," an exemplar of "monopoly capitalism" (p. 105). Pun shows how in a context of rarefaction of labour in China's coastal regions and a greater awareness of legal rights among workers, the IT giant $(1,400,000$ workers employed in China in 2010) managed to redeploy its production centres to interior regions (southwest, central, and north). This redeployment documented in the book reveals a great capacity for resilience among enterprises, especially in institutionally creating, with the active mediation of regional and local governments, new sources of labour that are more vulnerable and more easily exploitable. ${ }^{(3)}$ This is not without recalling similar processes studied previously at the level of history of global capitalism. (4)

Finally, the book also contains interesting information on the "second generation of migrant workers" (those born in the late 1980s and in the 1990s). The absence of predictability, security, and dignity defines in a more determining manner the condition and identity of migrant workers, as well as their modes of resistance and contestation of domination structures (p. 150). The author stresses that while differences between first and second generation workers should not be exaggerated, the second generation is on the whole more individualistic, better educated, clearly more oriented towards urban culture and consumption, and animated by an experience of indignity so pronounced that they nurture neither the hope of remaining in the city nor of returning to their native villages. In Pun's view, while the first generation of workers was characterised by the ephemeral nature of its condition, the second is characterised more by the notion of "rupture" through resentment and anger (p. 80).
To conclude, it may be pointed out that some chapters in the book rework articles previously published in journals by updating them and rendering them more accessible to readers who are not China experts or specialists in the political anthropology of labour. This effort at readability makes this work, which clearly articulates theoretical issues and concrete human experiences, accessible to a larger public. It should interest students, researchers, and teachers in the domain of contemporary Chinese studies and human and social sciences.

I Translated by N. Jayaram.

I Eric Florence is director of the CEFC (eflorence@cefc.com.hk).

2. Pun Ngai, "Becoming Dagongmei: The Politics of Identity and Difference in Reform China," The China Journal, No. 42, July 1999, pp. 1-19.

3. In Foxconn's case it took the form of recourse to trainees from vocational schools, with the help of municipal authorities in charge of employment and education, thus contravening labour laws.

4. See Robin Cohen, The New Helots: Migrants in the International Division of Labour, Cower, Aldershot, 1987.

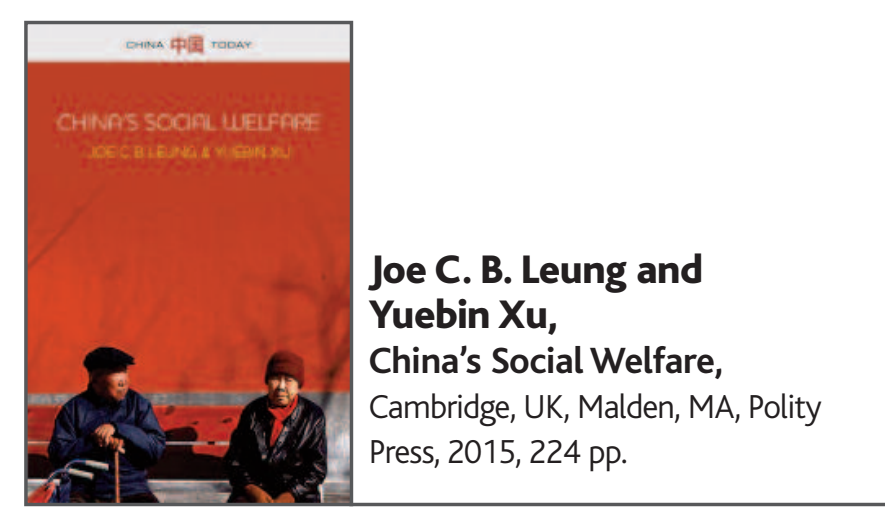

\section{CARINE MILCENT}

W ritten by Joe C. B. Leung and Yuebin Xu, China's Social Welfare: The Third Turning Point is a book that, within the space of some 200 pages, manages to describe the structure of China's major institutional developments in "social welfare," examining them from a historical perspective, as well as within the country's economic, demographic, legal, and social contexts.

China's new social welfare system covers the social protection system and its eligibility (social security benefits and pensions) as well as social services, and their accessibility in both financial and geographical terms. However, it also calls into question the notion of an egalitarian society and the level of economic development required to provide such wellbeing (xiaokang). This term is often associated with terms such as wellbeing, social development, and social policy. According to the definition coined by Elizabeth Segal in 2010 (Social Welfare Policy and Social Programs: A Value Perspective, Belmont, Brooks/Cole), then echoed by the authors: "In a wider perspective, it is the collective response to social problems."

The first publications to tackle the issue of social welfare began to appear throughout the 1980s. One of these was Dixon's Chinese Social Welfare System, 1949-1979, published in 1981 and among the first to provide data on the Maoist era. Other publications would follow throughout the 1990s, such as Cecilia Chan and Nelson Chow's More Welfare after Economic Reform? Welfare Developments in the People's Republic of China (1992), in 
which the authors analyse developments in wellbeing from both a historical and a theoretical perspective, and Joe Leung and Richard Naan's Authority and Benevolence: Social Welfare in China (1995), which brings to light the disruptive effects that the transition from socialist to market economy had on the social system.

The present publication examines the development of the Chinese social welfare system since 1949, a development that in recent decades has been defined by both economic factors (such as the marked proliferation and widening of inequality) and demographic factors (the one-child policy and ageing population). It raises three challenging issues that China is currently faced with. The first is the decentralisation of the economic decision-making powers that were established during the process of reform: the central state makes plans and plots out a course of action, while the provinces put the plans into practice as far as their budget will allow. The second challenge is linked to what was until very recently a period of incredible growth for China; growth, which in fact masks extreme wealth inequality between regions, as well as between rural and urban areas: factors that could lead to social instability. One of the central state's avowed goals is to spread economic growth into areas that have thus far benefited relatively little. The third challenge is the segmentation of Chinese society according to income, which means, among other things, that when it comes to social goods and services, offers via the market must coexist with regulated offers, and their respective levels of quality can vary enormously. Without a certain amount of wealth redistribution, it is likely that society would be forced to divide further still.

The book is divided into eight chapters. The first is an introductory chapter that presents an overview of changing expectations in terms of social welfare, and puts the subsequent chapters into perspective. In this chapter, the authors propose the terminology of the Confucian welfare state: one built on Confucian values that promote social stability, order as opposed to conflict, collective interests as opposed to individualism, obedience to authority, family obligations, the work ethic, and the importance of education. The second chapter offers a historical overview of the major economic and demographic indicators, and makes the point that the notion of social stability played a central role in the decision-making behind the successive reforms made to the social protection system. In particular, the authors draw our attention to the dismantling of the social protection system brought about by the establishment of a market economy, and the associated repercussions in terms of social welfare. Within this context, the third chapter takes stock of three demographic groups, each with distinct social needs: the two generations of only children, the elderly, and migrant workers. It outlines and comments on a set of economic indicators related to inequality, allowing the authors to set out the ways in which the social protection system could be considered lacking.

The fourth and fifth chapters set out the history of the reforms that have an influence on the social welfare system in China. Firstly, Leung and Xu make the distinction between social insurance and social assistance. In addition to social insurance for unemployment, work-related accidents, and maternity leave, the authors place considerable emphasis on healthcare programs, as well as the establishment of pensions for the elderly, who account for an ever-increasing share of the population. There are also historically rooted structural differences between rural and urban areas. Because of this, the authors split their presentation in two, focusing first on the evolution of reforms in urban regions, and, in the following chapter, analysing the situation and issues facing rural areas. It's important to note the in- creasing role of the position of migrants in the reforms that are taking place. The growing political awareness of the necessity to adapt certain public policies in order to account for migrant populations in cities goes beyond simply monitoring and managing the population, which was the case until recently. A growing preoccupation with the services on offer can now be observed, particularly for medical care and for the elderly. Nonetheless, the statistics put forward by Leung and Xu demonstrate that these reforms are not without obstacles. Throughout the presentation, the complexity of the system is made apparent, attempting as it does to juggle a desire to limit public expenditure while simultaneously providing a social welfare program within the context of the emergence of a competing care market. In other words, the central state is simultaneously promoting greater individual autonomy and a greater diversity of providers (public, private, and mixed), with a view to improving the quality on offer while also aiming to integrate China's poorest, most deprived people into the system. This double objective - which is complicated enough as it is - is subject to tight financial constraints: the percentage of GDP spent overall on social welfare is determined in advance. And all this is taking place within the context of the decentralisation of the social protection system.

The sixth chapter examines the various types of retirement and nursing homes. The authors highlight a shift in philosophy: from filial piety as the one and only means to ensure that the elderly are cared for, to the establishment of a welfare state (albeit in limited form and only to be used as a secondary option), combined with the creation of a funded pension system for future generations. Leung and $\mathrm{Xu}$ calculate the changes in health and social benefits provided to the elderly, and the social and economic inequalities that these benefits entail, both in rural areas and in cities (financial accessibility, geographic accessibility). In 1978 there were just 7,000 homes for the elderly, housing a total of 100,000 residents. Only the truly destitute, with no other source of assistance, were cared for free of charge. Now, with an ageing population of up to $30 \%$ in places such as Shanghai, and extremely varied levels of income, a large number of reforms have been imposed, notably by broadening the apparently inadequate market to include both public and private operators, with a view to improving the quality and quantity of healthcare and social support.

The seventh chapter is distinct from the others, outlining innovative social management that includes NGOs, independent social workers, and the purchase of services (POS). As the authors point out, the state's decision-making betrays a stark contradiction between the constraints imposed upon these structures and the political awareness of a real social need for these structures to be more widespread, especially given the ageing population and the need to manage social unrest. This could end up redefining the relationship between two camps that, until now, have always displayed a close interdependence (the financial and the legal).

As we have seen, the authors provide a detailed account of the series of reforms to China's social protection system, the development of a marketoriented offers system, and a broad picture of the changing demands of social welfare. Drawing upon a wide array of official sources and scientific articles, the book highlights the reforms' most significant achievements, including the establishment of universal public insurance, covering almost the entirety of the population. That said, it also reveals a process of fragmentation at work in the social protection system, borne out by the fact that the implementation of reform has been delegated to the provinces (which do not have the resources to match) while the government dispenses political directives and financial support. In their conclusion, Leung and Xu question 
the future management of inequality and its economic repercussions.

This robustly researched book will be invaluable to anyone wishing to gain a comprehensive overview of social welfare in China.

\section{Translated by David Buchanan.}

I Carine Milcent, CNRS-researcher and professor at Paris-Jourdan Sciences Économiques (PSE), has been on assignment at CEFC since 1 September 2014 (cmilcent@gmail.com).

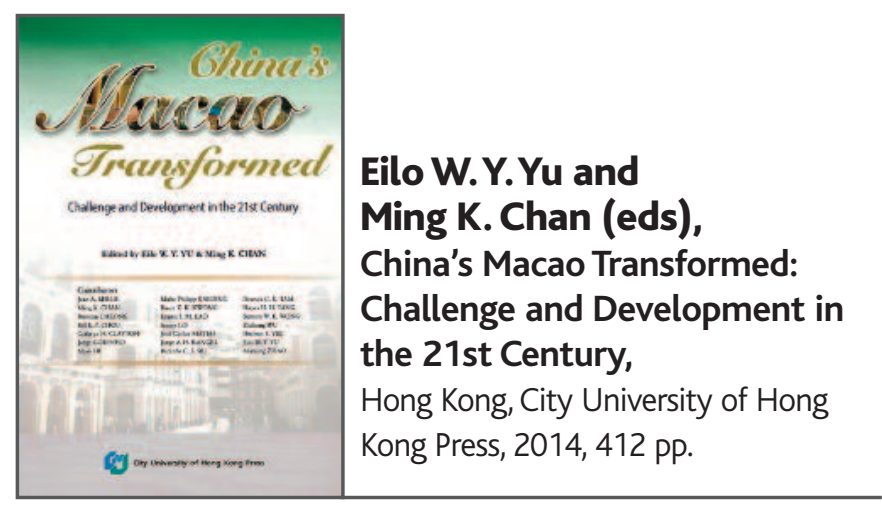

\section{ÉRIC SAUTEDÉ}

$\mathrm{B}$ ooks dealing with current affairs in Macao, whatever the language, do not come often; good publications about Macao are even rarer. At least three sets of reasons can explain this dearth of academic production. First, the Special Administrative Region is small - 650,000 inhabitants on a land area of slightly more than $30 \mathrm{sq} . \mathrm{km}$ - and thus does not attract much attention, as its relevance within the broader perspective of China's evolution is considered marginal and is clearly over-shadowed by Hong Kong's more sophisticated, buoyant, and challenging development. Second, it is commonly acknowledged that starting in 1967, in the wake of the "12.3" incident, Macao's polity, even under the Portuguese colonial administration, has yielded to the People's Republic of China's views on its future, and thus any publication regarding Macao somehow constitutes an update of that deferential position - hence not requiring frequent repetition. And third, sources and surveys, when available and/or funded, often exclude one another: government-sponsored research in social sciences is rarely made public and often gets trapped in excessive praise or un-analytical rebarbative descriptions, while more critical writings, when firmly grounded in first-hand and meaningful investigation, often address segmented narrow issues.

The edited volume published by the City University of Hong Kong somehow comes as a counterpoint to these assumptions, thus showing that Macao is indeed a wonderful laboratory for social sciences, not only in itself but also within the Chinese "living tree," according to the expression of Tu Weiming, and as an embodiment of the "one country-two systems" formula in particular, and a case study of "partial sovereignty" in general. This book is therefore a must-read for anybody with an interest in Macao. Moreover, being a collective work divided into five sections - a long introductory and contrasted first part (105 pages by four authors!), followed by the usual politics, socio-economic issues, socio-cultural concerns, and finally external relations comprised of 15 contributions - this volume easily allows for browsing and selecting among very diverse takes. To choose but one exam- ple, the admirable final chapter authored by Cathryn Clayton on "Macao Local, Macao Clobal" acts as a conclusive and far-reaching reflection on the hybrid nature of Macao today, but it will also be of great interest to scholars of globalisation and identity-building alike. The great merits of this publication cannot be stressed enough: first of all because this is the end-product of various seminars and conferences held in Lisbon, Canada, Hong Kong, and Macao starting in 2009; and second because it is one of the few, if not only, truly academic publications released in 2014 in English on the occasion of the $15^{\text {th }}$ anniversary of the handover. In this age of excessive celebration for everything and anything, this very fact speaks volumes about the precious character of the whole enterprise.

But being a collective endeavour also has the usual drawbacks, which deserve to be stressed. If one cannot blame the book for not being comprehensive, there are several important "loopholes": Bill Chou's chapter on public sector reform is well-rounded, but an additional contribution on public services would have been welcome; then, when it comes to external relations, Macao's place in international organisations or as a signatory to international covenants and agreements deserves attention, and clearly the connection to Europe goes beyond Portugal and Portuguese-speaking countries, even though José Carlos Matias' essay on the latter is - as usual - very thorough. Then, collective books are rarely even in the quality and length of the contributions, and unfortunately this one is no exception. The chapter on political reform written by a law professor is far too short, analytically limited, and clearly too static. The chapter on patron-clientelism and elections - such an important feature of Macao politics - fails to bring anything new (tongxiang associations deserve a special section!) and simply ignores significant previous publications such as those by Annie Lee Shuk-ping and Lam Wai-man. One of the chapters on identity within the socio-cultural section is grounded on very incomplete data, thus resulting in far-fetched conclusions bordering on the bizarre while mixing Mandarin and Cantonese transcriptions for no justifiable reason - the name of the cousin of the Chief Executive is transcribed as either Chui Sai Peng (usually) or (very rarely) Cui Shiping in pinyin, but not as Chui Shiping!

Yet, most of the papers are truly remarkable, starting with Eilo Yu's introduction, which is an extremely courageous, thought-provoking, and wellargued demonstration of the most salient aspects of the "debacle" of the "one country-two systems" formula in Macao, although he trusts that it is never too late to turn things around. Then, in order of appearance, several chapters deserve a special mention for the quality of their research or the novelty they provide: Herbert Yee's update on the practice of "one country-two systems"; Sonny Lo's renewed exploration of casino capitalism; Ricardo Siu and Miao He's detailed exposition of the casino economy model at work; Hayes Tang's thorough examination of the constraints weighing on academic freedom in tertiary institutions; Derrick Tam's extensive and case-study based analysis of the interaction between heritage protection, tourism, and urban planning; Minxing Zhao's original take on North Korean assets transiting through Macao, and how the case of Banco Delta Asia can be seen as the perfect and renewed illustration of the common Chinese idiom of "killing a chicken to scare the monkeys"; and again, the closing chapter of Cathryn Clayton on a possible narrative to better articulate the transformation of a local identity that is both passive and active when confronting global forces.

To be honest, even the long introductory part, besides Eilo Yu's incisive opening, actually justifies an attentive read. Three very different if not contradictory perspectives act as a stimulus for what is to come in the volume: 